\title{
REDES SOCIAIS E PAISAGEM DA DESTINAÇÃO TURÍSTICA: FOTOGRAFIAS ONLINE NA CONSTRUÇÃO DA IMAGEM DA CIDADE
}

\author{
SOCIAL MEDIA AND LANDSCAPE FOR TOURIST DESTINATIONS: \\ ONLINE PHOTOGRAPHY IN THE CREATION OF CITY IMAGE
}

\author{
Luciana Noronha Pereira*
}

Alina Gonçalves Santiago**

\section{RESUMO}

A atividade turística tem as paisagens entre seus principais atrativos. Registros fotográficos, como fragmentos da realidade, são produtos de um olhar a aspectos da paisagem e mediadores do seu processo de significação. Novas formas de registrar e compartilhar a experiência turística - em fotografias digitais produzidas e compartilhadas online - têm implicado na ampliação de seu efeito e possibilitado novos tipos de apropriação, interação e criação do espaço. Este estudo pretende investigar possíveis influências das fotografias online na imagem de destinações turísticas a partir de Balneário Camboriú (SC). A metodologia inclui uma etapa quantitativa quantidade e localização das fotos - e uma etapa qualitativa - análise de conteúdo das fotos e os comentários a elas. A concentração de fotografias online em áreas de orla e a presença predominante de elementos naturais como argumentos centrais, associados a emoções positivas, destacam-se entre os resultados.

Palavras-chave: Redes sociais. Paisagem urbana. Fotos online. Destinações turísticas.

\section{ABSTRACT}

Landscape is among the main appeals of tourist attractions. Photography, just like fragments of reality, is the product of the attention given to landscape aspects, and mediates the significance process. New ways of documenting and sharing travel experiences — through digital photography produced and shared online- have resulted in the expansion of its effect, enabling new forms of appropriation, interaction and space creation. This study aims at investigating possible influences caused by tourist destinations online photography of Balneário Camboriú (SC). Methodology includes quantification-amounts of photos, and locations where they were taken-, and qualification-content analysis and comments on the photos. Among the results, emphasis of online photography falls on fringe areas, and the predominance of natural elements as main subjects, associated with positive emotions.

Keywords: Social Media. Urban Landscape. Online Photos. Tourist Attractions.

\footnotetext{
* Universidade do Vale do Itajaí.

Quinta Avenida, s/n, Municípios, CEP 88330-000, Balneário Camboriú, SC, Brasil.

CV: http://lattes.cnpq.br/1204291649938217

lunope@gmail.com

** Universidade Federal de Santa Catarina.

Programa de Pós-graduação em Arquitetura e Urbanismo (PósARQ).

Campus Reitor João David Ferreira Lima, Caixa Postal 476, CEP 88040-900, Trindade, Florianópolis, SC, BR.

CV: http://lattes.cnpq.br/5182318318276740

alinagsantiago@hotmail.com
} 


\section{PAISAGEM, DESTINAÇÕES TURÍSTICAS E NOVAS TECNOLOGIAS}

O desenvolvimento da atividade turística está inextricavelmente vinculado a uma base geográfica a partir da qual é implantado e na qual opera. A paisagem, enquanto produto da sobreposição e das permanências ao longo do tempo (SANTOS, 1992), por diversas vezes constitui o principal argumento da atratividade da destinação turística (OLIVEIRA; FERNANDES; STACH, 2007), seja este de maior ou menor destaque, tal como os elementos publicitários, que, conforme afirmam Casarin e Santiago (2013), podem determinar alterações em sua percepção.

Os cenários urbanos proporcionados pela paisagem possuem relações inesgotáveis com a atividade turística e com os significados e sentidos a eles atribuídos (URRY, 1999). Esse conjunto é capaz de gerar determinadas expectativas e atrair públicos específicos, embora possa haver conflitos entre as preferências de residentes e turistas ou de diferentes grupos de turistas (CONCU; ATZENI, 2012).

A imagem projetada da destinação, enquanto lugar e características desejados, é construída a partir da mídia, incluindo elementos como cartões-postais, fotografias, notícias, textos, nos quais a fotografia ocupa lugar central. Ao mesmo tempo, as fotografias produzidas por usuários, turistas ou residentes fazem parte de uma narrativa da experiência espacial turística (LARSEN, 2005; LO, MCKERCHER; CHEUNG, 2011) e constituem linguagens que denunciam a forma de olhar, a valoração e a ênfase a determinados elementos (TACCA, 2005).

A produção e a interpretação fotográficas são compreendidas enquanto processos permeados pela cultura, capazes de permitir o estabelecimento de relações entre os usuários e suas vivências no processo de significação dos lugares (COSTA; BENITES, 2009). Por outro lado, as novas formas de registrar e compartilhar a experiência turística e os elementos constituintes da paisagem através de fotografias produzidas e compartilhadas online têm implicado na ampliação de sua audiência e efeito (LO; MCKERCHER; CHEUNG, 2011), possibilitando novas formas de apropriação, interação e criação do espaço (LEMOS, 2010).

A generalização da produção e da divulgação de fotografias foi possibilitada pela popularização de novas tecnologias, ampliando o acesso e a produção de informação por público não especializado e não vinculado ao mercado turístico, ou seja, ideologicamente descomprometido com o trade, através de mídias pós-massivas (LEMOS, 2010), tendo seus efeitos multiplicados pela audiência de uma rede geograficamente dispersa de estranhos (LO; MCKERCHER; CHEUNG, 2011). Também tem possibilitado a criação da memória visual dos lugares, mesmo antes de conhecê-los, e reflexões mais amplas sobre o espaço social (MULLINS, 2014).

Assim, as novas tecnologias de informação e comunicação (TICs) permitem novas fontes de informação, independentes sobre os destinos, e tendem a mediar a experiência de viagem, interferindo nas escolhas de o que fazer e conhecer na destinação turística. 


\section{DIMENSÃO TURÍSTICA DO ESPAÇO GEOGRÁFICO E NOVAS TECNOLOGIAS DE INFORMAÇÃO E COMUNICAÇÃO (TICS)}

O espaço geográfico é reflexo e condicionante das diversas relações sociais (SANTOS, 1992), campo para manifestações e conflitos sociais coexistentes, incluindo o desenvolvimento da atividade turística. A atratividade turística definida por Beni (1999, p. 8) como "[...] aspectos característicos do local e seus respectivos diferenciais turísticos, e todas as atividades desenvolvidas em função deles" tem na paisagem seu principal componente (OLIVEIRA; FERNANDES; STACH, 2007).

Para Leite (2006, p. 82), a paisagem pode ser entendida como um conjunto de elementos visíveis, de certa durabilidade e estabilidade temporal "[...] e pela trama parcialmente invisível da estrutura social". O autor considera seu caráter dinâmico, já que ao mesmo tempo em que a paisagem pode definir modificações ou limitações às estruturas sociais, estas podem, a partir de suas alterações e novas necessidades, surgidas em decorrência, sugerir "[...] novas formas e redefinem [redefinir] os valores da paisagem visível" (LEITE, 2006, p. 82).

A implantação da atividade turística enquanto parte da estrutura socioeconômica de diversas localidades tem contribuído de modo decisivo para a alteração das dinâmicas locais. De outro lado, sua inserção no contexto da sociedade capitalista e do meio técnico-científico-informacional (SANTOS, 1996) confere à atividade alcance mundial, mesmo quando em localidades tidas como remotas ou com menores vantagens locacionais, dada sua posição geográfica, especialmente quando da utilização das novas TICs.

Nesse contexto, Duarte e Firmino (2009) fundamentam e contextualizam os conceitos de espaço aumentado e cidade infiltrada enquanto fenômenos urbanos contemporâneos. O primeiro é impulsionado pelo crescimento da utilização e presença cada vez mais permanente e imperceptível de TICs em diversos sistemas e estruturas da vida urbana. Já ao segundo conceito, cidade infiltrada, são associadas a invisibilidade e onipresença das TICs que ampliam o poder de comunicação e alteram as formas de interação, acontecendo em todos os lugares, a qualquer momento, independentemente do nosso conhecimento.

Lemos (2010) afirma ainda que as mídias pós-massivas são capazes de reconfigurar os espaços urbanos, tornando as cidades mais complexas, gerando novas territorialidades, marcadas notadamente por seu caráter híbrido. Ao mesmo tempo, Marchi (2014) enfatiza a importância das mídias locativas no registro das experiências urbanas e dos celulares como produtores de novas linguagens.

\section{PAISAGEM E SEUS SIGNIFICADOS ATRAVÉS DOS SITES DE REDES SOCIAIS}

A paisagem é definida, estruturada e explicada pela morfologia urbana, e esta, como o estudo das formas que compõem a cidade, considerando os fenômenos que lhes deram 
origem (LAMAS, 2004). Assim, a significação das formas constituintes e organizadoras da paisagem se relaciona diretamente à vivência e às experiências no espaço.

Seu caráter dinâmico é ainda evidenciado através do papel humano na definição da paisagem (VERDUM, 2012), tanto na construção e alteração dos seus elementos físicos quanto na sua construção, percepção e significação - ideia com a qual Correa e Rosendahl concordam, caracterizando a paisagem enquanto unidade bilateral que não existe sem o sujeito humano, com o qual forma um conjunto integrado que "se autoproduz e se autorreproduz" (CORREA; ROSENDAHL, 1998, p. 10). Para Capra (2002, p. 86), a dimensão do significado constitui "[...] uma expressão sintética do mundo interior da consciência reflexiva", e é originada a partir dos contextos social e cultural, da autoconsciência e da linguagem. Essa dimensão - essencial e inerente aos fenômenos sociais - e as dimensões de forma, matéria e processo - presentes em todos os sistemas vivos - implicam na compreensão de que o sentido de determinado fato, elemento ou coisa não se encerra em si, mas que a partir dele é associada uma multiplicidade de atributos e adjetivos que permitirão sua interpretação.

Entendendo a paisagem como construção social, torna-se determinante reconhecer sua dimensão simbólica. Compreendendo o interesse da atividade turística em determinados aspectos da paisagem - "o olhar do turista é construído através de signos, e o turismo abrange uma coleção de signos" (URRY, 1999, p. 18) - bem como destas características como um produto a ser comercializado, faz-se necessário verificar se as imagens e expectativas desse consumidor são capazes de serem satisfeitas ou não por determinado lugar. Oliveira, Fernandes e Stach (2007, p. 92) afirmaram: "[...] a paisagem urbana [...] possui símbolos que podem e devem ser interpretados pelo turista, de forma que este possa descobrir a cidade, sua história, seus costumes, seu modo de vida, enfim, sua cultura".

$\mathrm{Se}$, por um lado, os processos de construção do significado de uma paisagem podem ser definidos pelas relações sensoriais diretas entre usuário e ambiente e pela acumulação de experiências espaciais nas quais a presença corporal em determinado espaço media as conexões de ideias, por outro, ideias veiculadas por diferentes mídias, de massa ou pós-massivas - como postais, fotografias, notícias, relatos de amigos também são capazes de interferir e possibilitar o processo de significação mesmo sem contato direto com tal ambiente ou paisagem.

A crescente utilização de novas TICs para a busca de informações e como recurso de apoio ao processo de tomada de decisão de compra ou escolha do destino turístico tem atuado também na criação de determinadas imagens e expectativas acerca das localidades (XIANG; GRETZEL, 2010).

A busca dessas informações através das redes sociais lança novas perspectivas de interação quando permite que as informações também sejam veiculadas pelo usuário, ou seja, além das informações produzidas e divulgadas apenas pelos executivos de marketing das destinações, incluindo a perspectiva de sua construção a partir da experiência do usuário (XIANG; GRETZEL, 2010), em consonância com as afirmações de Lemos (2010) acerca das mídias de caráter pós-massivo. 
Reed e Johnson (2014) agregam também as noções de mobilidade e fluidez como características de um mundo digitalmente mediado, que permite a produção e o compartilhamento de informações - inclusive fotografias e experiências turísticas -, alternando o contato com grupos sociais a qualquer momento. Segundo os autores, a utilização de dispositivos pessoais e portáteis, como smartphones, amplia a capacidade de alternar instantaneamente entre identidades e grupos, ou seja, entre diferentes mundos sociais.

Soma-se à disponibilidade de informação o incremento de sua utilização para produzir informação personalizada em redes sociais e recuperar informações por meio de mecanismos de busca que têm beneficiado tais redes (XIANG; GRETZEL, 2010). Assim, as experiências, impressões, sensações e significados acerca das paisagens visitadas quando da atividade turística podem ser compartilhadas e acessadas por outros usuários, dando-lhes nova amplitude.

Kramer, Guillory e Hancock (2014) discutiram evidências de que as emoções expressas através das redes sociais são capazes de influenciar as emoções daqueles que visualizam mensagens de modo "contagioso", massivo, em grande escala, lembrando que o contágio emocional é comprovado através do contato presencial entre os seres humanos. Afirmam, ainda, que há indícios de que tal contágio ocorre também em outros aspectos, de modo que as experiências pessoais também podem influenciar as experiências de outras pessoas, tal como as experiências urbanas ou turísticas: "[...] mensagens online podem influenciar nossa experiência de emoções, podendo afetar uma variedade de comportamentos off line" (KRAMER; GUILLORY; HANCOCK, 2014, p. 8.790; tradução das autoras).

Portanto, a construção da imagem acerca das paisagens nas redes sociais tende a ser influenciada a partir das emoções e experiências relacionadas - tanto mais quanto forem os hábitos e as condições de acesso às redes pelo público-alvo de determinada destinação.

\section{FOTOGRAFIA ONLINE ENQUANTO LINGUAGEM E A EXPERIÊNCIA TURÍSTICA}

Tal como a paisagem, a produção e a interpretação de imagens fotográficas são permeadas pela cultura. Nesse sentido, Costa e Benites discutiram a possibilidade de sua utilização como linguagem, relacionando sujeitos aos lugares e às suas vivências, de modo que "[...] as imagens, e, portanto, a fotografia, tem um papel fundamental para compreender o processo de significação dos lugares pelos sujeitos", situando a fotografia enquanto categoria imagética complexa (COSTA; BENITES, 2009, p. 2).

Essa complexidade é definida pelo caráter de verossimilhança, atribuído à fotografia enquanto técnica, mas também pelo caráter subjetivo e "oculto" contido no sujeito-fotógrafo que percebe determinados aspectos da paisagem, seleciona ângulos, enquadramentos, condições de iluminação, elementos que deverão ou não ser incluí- 
dos. A fotografia, assim, é capaz de transmitir ideias, conceitos, concepções estéticas, significados, contrapondo elementos reais a elementos ocultos. Assim, a paisagem e as suas representações também são, parcialmente, resultados do que há na mente do observador. Conforme Tacca (2005, p. 4), "[...] a imagem como representação cultural, seja ela na sua carga simbólica, epistêmica ou estética, é de qualquer forma uma construção de conhecimento da realidade".

Se a fotografia seleciona, direciona, exclui determinados aspectos da paisagem, é possível afirmar que a aplicação dos princípios da composição fotográfica é capaz de modificar a percepção de seu leitor (COSTA; BENITES, 2009). A afirmação de Malard (2006) - de que a interpretação de uma obra (neste caso, fotográfica) é uma descrição de caráter pessoal, que sempre excede à própria obra, não podendo ser desvinculada da existência humana - contribui com essa ideia.

Dubois (2003) e Kossoy (2002) estudaram a fotografia à luz da teoria semiótica de Charles Sanders Peirce. O primeiro analisa o percurso histórico através do qual se deu a evolução dos modos de compreender a fotografia segundo três momentos, em uma perspectiva peirciana "[...] da verossimilhança ao índice" (DUBOIS, 2003, p. 27): 1) como espelho do real, no qual a fotografia era entendida como prova da existência e realidade do objeto; 2) como transposição do real, compreendida como impressão e transposição da realidade; 3) como um traço do real, representando apenas certos atributos deste em determinado instante. Kossoy (2002) estabelece uma relação de proximidade entre o processo fotográfico e o processo triádico semiótico, na qual é possível relacionar o assunto ao objeto, a tecnologia ao signo e, finalmente, o fotógrafo ao interpretante, enquanto mediador da representação do real por ele construída.

Entender a fotografia como representação e linguagem passa a constituir-se em pressuposto da semiótica, de modo que "[...] a foto não é uma simples réplica da realidade em questão, mas sim uma transformação visual que deve ser novamente interpretada pelo observador a fim de assegurar a informação necessária" (SANTAELLA; NÖTH, 1998, p. 41).

Lo, Mckercher e Cheung (2011) acrescentaram a atividade turística à discussão, para além da utilização fotográfica como prova da visita, do contato físico da pessoa com o lugar, mas também desempenhando papel na construção das memórias de viagem, auxiliando em suas narrativas e ocupando papel simbólico (LO; MCKERCHER; CHEUNG, 2011). Ao mesmo tempo, afirmaram a capacidade da fotografia e das construções de memória a ela associadas de tornar a experiência de viagem - intangível por princípio - em algo tangível, a partir da possibilidade de dirigir, estruturar e medir essas experiências. Larsen (2005) acrescentou que a fotografia turística é menos visual e mais uma personificação de ideias e da experiência turística; menos direcionada ao consumo de lugares e mais direcionada à construção de relações sociais. $\bigcirc$ autor defende que a natureza da fotografia turística é muito mais complexa e teatral, chamando-a de uma encenação de "geografias imaginárias" (LARSEN, 2005, p. 417). 
Complementarmente, a categoria de fotografias conhecida como selfie é discutida por Mullins (2014), que reafirmou a importância desses registros fotográficos, possibilitando a formação de memórias visuais acerca de lugares históricos mesmo antes de conhecê-los, ainda que, muitas vezes, essas selfies tenham sua compreensão reduzida a "exibições do ego". O autor discutiv e apresentou estudos que relacionam a produção das selfies com a vivência do lugar, podendo caracterizar uma das formas de anotação digital, tal como definiu Lemos (2010), inserindo o sujeito histórica e visualmente no lugar, permitindo a articulação de seus significados (MULLINS, 2014).

Por outro lado, a ampla utilização das redes sociais para a publicação de fotografias de viagem permite a ampliação exponencial da audiência para pessoas com as quais são compartilhadas as imagens fotográficas - a que Lo, Mckercher e Cheung (2011) fizeram referência, ampliando-a para uma rede geograficamente dispersa de estranhos. O potencial de exposição de uma foto postada online em um site de redes sociais possibilita atingir uma rede de "[...] dezenas de milhares de 'amigos'" (LO, MCKERCHER; CHEUNG, 2011, p. 730).

É importante destacar que a utilização das fotos online possibilita que as viagens se tornem mais evidentes enquanto forma de autoapresentação, especialmente entre os mais jovens (LO; MCKERCHER; CHEUNG, 2011), dado que acrescenta aspectos da construção da identidade individual do turista à complexidade e subjetividade já presentes no processo de construção da imagem e da escolha das destinações turísticas.

Para Mullins (2014), as fotografias online enquadradas como selfies atuam como uma forma de representação visual orientada para questões ideológicas da atratividade, que molda como as pessoas veem as selfies e, desse modo, tendem a influir na construção da imagem de determinada destinação turística, permitindo o surgimento da referida memória visual mesmo anteriormente ao contato físico direto com dada destinação, seus atrativos, seus elementos constituintes e suas paisagens. $O$ autor corrobora as ideias de Lo, Mckercher e Cheung (2011) quando afirma que tal forma de registro também pode indicar a consciência de nossa aparência e de que somos observados, constituindo uma forma de "compartilhar" nossa aparência com os demais da forma como queremos ser vistos, participando da ânsia e atuando no sentido da construção da própria identidade. É o surgimento da possibilidade de digitalização das fotografias, integrante e associado às novas TICs, que possibilita novos mecanismos de reflexões mais amplas sobre o espaço social (MULLINS, 2014).

A tendência de ampliação da utilização das mídias online por turistas é ainda reforçada por outro aspecto, apontado por Lo, Mckercher e Cheung (2011) quando afirmam que as mesmas pessoas que costumam postar suas fotos e informações de viagem também tendem a buscar informações semelhantes com pessoas cujos interesses estão em atividades similares. Segundo os autores, esses itens tendem a ser consultados em busca de confiabilidade. Portanto, as selfies e as demais categorias de registros fotográficos, produzidos em lugares históricos e demais localidades turísticas, possibilitam e fazem parte do processo de conferir significados à experiência pessoal do turista (MULLINS, 2014). 
[...] se consumir é existência e pertencimento na sociedade de consumo, a presença individual ou coletiva na web através dos blogs é necessidade dessa sociedade e produz visibilidade nunca antes alcançada por nenhum outro meio de comunicação. Desta forma, proporciona também que uma grande diversidade de grupos sociais possa hoje expor uma autoimagem construída para o "outro" internáutico e com ele manter interatividades, participando do espetáculo visual da contemporaneidade (TACCA, 2005, p. 8).

Muito mais do que provas documentais da realidade, as fotografias constituem-se tal como linguagem, ainda que seu código seja menos normatizado e mais flexível que a linguagem verbal, tornando-se importante recurso para o entendimento das imagens e imaginários urbanos criados, interpretados e projetados a partir de características concretas do espaço da cidade ou de determinada destinação turística, da morfologia urbana - universos nos quais pode ser inserida a imagem turística - e, consequentemente, da paisagem.

\section{METODOLOGIA UTILIZADA}

A abordagem definida para esta pesquisa é qualitativa, de natureza exploratória, tendo seu percurso metodológico composto de dois estágios principais: o primeiro, quantitativo; o segundo, qualitativo.

O ranking visual e dinâmico, segundo a área visualizada no mapa, disponibilizado online na rede mundial de computadores pelo instrumento Sightsmap, sistematiza a quantidade de fotografias publicadas online, com geolocalização através do Panoramio, convertendo-as em um "mapa térmico" interativo e identificando com cores os locais mais fotografados do mundo (amarelo para os mais fotografados, passando pelo laranja, vermelho, magenta, lilás e cinza para os menos fotografados).

As informações disponibilizadas permitem identificar os locais mais fotografados no município de Balneário Camboriú (SC), situado entre as áreas mais fotografadas no estado de Santa Catarina. Por meio desse aplicativo é possível definir a área do mapa na qual se quer construir o ranking, bastando movê-lo para tal, assim como definir o número de posições desejadas no ranking (de cinco a mil posições). Entretanto, há uma limitação do aplicativo com implicações para esta pesquisa: não exibir dados de quantidades de fotos para cada local ranqueado, mas apenas sua posição no ranking das localidades demonstradas no mapa e sua posição quando considerado o ranking mundial.

Os dez pontos mais fotografados do município nesse ranking (segundo dados coletados em junho de 2014 e atualizados em junho de 2017, mantendo-se o ranking na área utilizada na pesquisa) foram utilizados para definir pistas para a busca de imagens publicadas online no Instagram, através do mecanismo de monitoramento de redes sociais chamado Scup, cujo escopo principal é o monitoramento e gestão de marca (coleta de imagens feita nos meses de junho e julho de 2014 e sistematização e análise em agosto e setembro de 2014). O Instagram constitui uma rede social 
enquadrada, conforme Xiang e Gretzel (2010), como "site de compartilhamento de mídias", contribuindo aos objetivos deste estudo, no qual as fotografias estão entre os principais elementos de análise, assim como possibilita a replicação vinculada destas publicações no Instagram, também no Facebook, segundo Xiang e Gretzel (2010), um "site de rede social". Ambas redes sociais foram as mais utilizadas no compartilhamento das fotos de viagem, segundo o estudo de Lo, Mckercher e Cheung (2011), de amplo alcance e capaz de desencadear o processo de contágio emocional (KRAMER; GUILLORY; HANCOCK, 2014).

Essas fotografias coletadas foram analisadas primeiramente de modo quantitativo, procurando quantificar os locais e os principais elementos componentes da paisagem, através dos elementos morfológicos que a definem e conformam. Posteriormente, estas mesmas fotografias foram submetidas a uma análise de natureza qualitativa de conteúdo, com abordagem semiótica - segundo a qual a fotografia é compreendida como linguagem. A análise de conteúdo permitiv o agrupamento das imagens coletadas em cinco categorias preliminares que serão apresentadas nos resultados desta pesquisa.

\section{BALNEÁRIO CAMBORIÚ (SC) ATRAVÉS DE FOTOGRAFIAS ONLINE PUBLICADAS EM REDES SOCIAIS}

Se, quanto mais aderida dada localidade está em relação às modernizações citadas por Santos (1994), mais luminosa é a zona na qual se situa (SANTOS, 1994) - e entendendo a publicação de fotografias online como parte desse processo -, pode ser verificado que, no contexto do estado de Santa Catarina, a porção do território mais aderente, e, portanto, mais adaptada ao meio técnico-científico-informacional (SANTOS, 1996), é o litoral, especialmente em sua porção centro-norte - na qual estão situadas a capital do estado, Florianópolis (onde se encontra o local mais fotografado na área), sua cidade mais populosa, Joinville, e Balneário Camboriú (o segundo local mais fotografado na área), objeto deste estudo (figura 1).

A lógica de ocupação do território brasileiro, dada principalmente e concentradamente a partir do litoral e de seus rios, que permitiram o acesso e o surgimento das primeiras cidades, é reforçada pelas lógicas socioeconômicas, ambientais e espaciais da atividade turística, que busca no litoral e em suas áreas próximas elementos de interesse - atrativos - e amenidades (CORREA, 1995), em torno dos quais se desenvolve, muitas vezes, destruindo as mesmas características que suscitaram interesse (RUSCHMANN, 2003; GOELDNER; MCINTOSH; RITCHIE, 2002), iniciando a decadência em seu ciclo de vida (BUTLER, 1980). Parece possível inferir, também, talvez exatamente em função dos processos citados anteriormente, que estas áreas foram mais atingidas e afetadas pelas novas TICs.

Do mesmo modo, no contexto de Balneário Camboriú, verifica-se a forte concentração de fotografias online junto ao litoral, aos atrativos turísticos, nas áreas com maior concentração de amenidades e, sobretudo, nas áreas de interesse do capital 
- que também correspondem às mais dotadas de infraestrutura e concentradoras dos investimentos públicos (LIZ; PEREIRA, 2012).

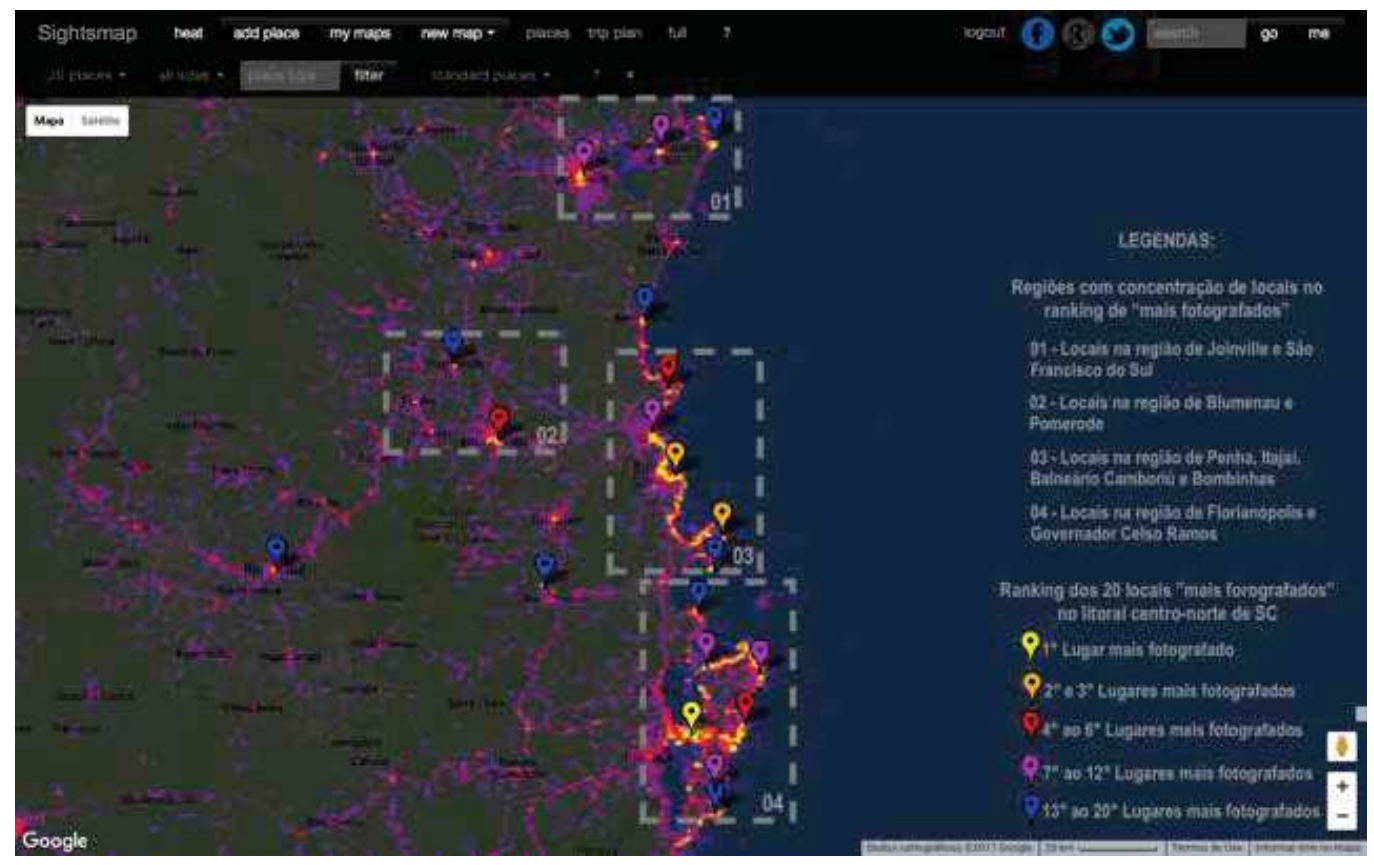

Figura 1 Os 20 locais mais fotografados da região centro-norte do estado de Santa Catarina (BR), com destaque para a concentração de pontos ranqueados no litoral.

Fonte: Adaptado por Luciana Noronha Pereira e Alina Gonçalves Santiago a partir do ScreenShot de Sightsmap, 2014, e atualizado em 2017.

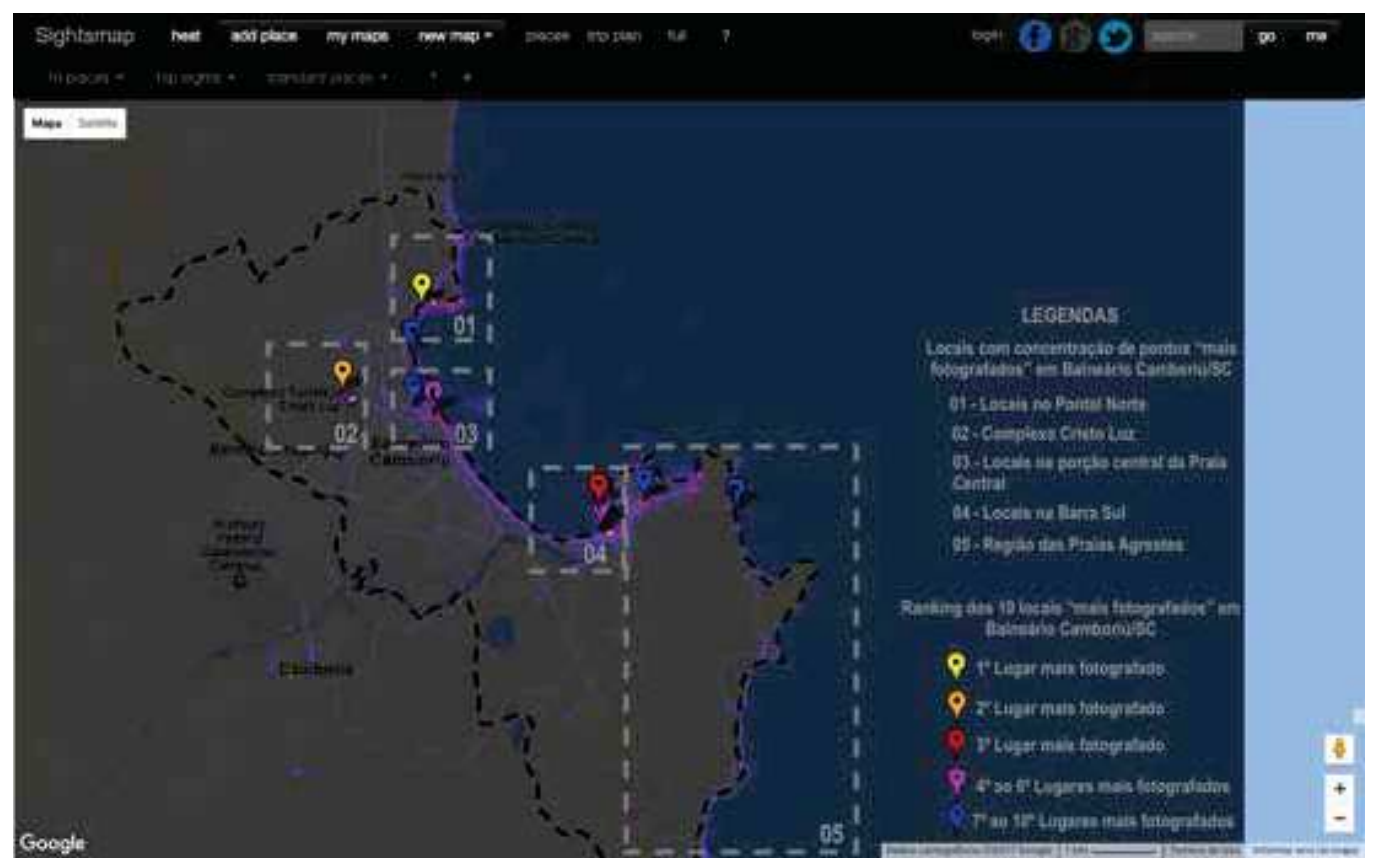

Figura 2 Os dez locais mais fotografados em Balneário Camboriú (SC).

Fonte: Adaptado por Luciana Noronha Pereira e Alina Gonçalves Santiago a partir do ScreenShot de Sightsmap, 2014, e atualizado em 2017. 
O ranking demonstrado pelo Sightsmap - de caráter dinâmico, atualizado segundo as publicações de fotos a partir das fotografias publicadas no Panoramio e indicadas pelas cores - marca os dez locais mais fotografados no destino no período da coleta, junho de 2014 (figura 2). Destaca-se que dois destes lugares - Pontal Norte e Barra Sul -, com pequenas variações de posicionamento, ocupam cinco das dez localizações marcadas pelo site, cujo mecanismo agrupa as fotografias em determinado raio desses espaços à beira-mar. Se, de um lado, ao dividir as fotografias marcadas por três diferentes posições em um mesmo local pode dar a impressão de menor importância, dado seu ranking, de outro, isso permite inferir que, caso tais fotos fossem tomadas em um único conjunto em cada um dos locais - Pontal Norte e Barra Sul -, possivelmente haveria uma mudança do citado ranking.

O único local da cidade presente nesse ranking e fora das áreas de orla é o Complexo Turístico Cristo Luz, onde existe um mirante e alguma estrutura turística instalada sobre um morro, com ampla visão da cidade, cuja estrutura é utilizada para a realização de eventos, o que também determina a ampliação da quantidade de fotografias compartilhadas.

No segundo momento desta pesquisa, foram coletados dados do Instagram, a partir do aplicativo Scup, objetivando, ao mesmo tempo, utilizar os resultados obtidos através do Sightsmap, contrapô-los aos resultados de outra rede social e ter a possibilidade de incluir os comentários associados às fotografias.

O primeiro resultado a destacar é a predominância de comentários positivos associados às fotografias postadas. No entanto, é necessário ressaltar que a presença massiva destes pode ter relação com os locais levantados, já que todos são áreas de interesse turístico e mais bem ranqueados. Por outro lado, também pode haver influência da identidade que os sujeitos querem construir através das redes sociais, centrada na autoafirmação, na ênfase dos aspectos positivos da própria vida. A postagem das fotos concentrou-se no domingo, na segunda e na terça-feira. É possível que a postagem ocorra após a produção das fotos durante o final de semana (e não instantaneamente), ou, ainda, que o público que mais produz e posta fotos durante as atividades o faz independentemente do dia, útil ou não, tal como turistas.

No que diz respeito às pistas com maior representatividade nos resultados, ou seja, aos locais com mais fotografias online postadas no Instagram, verifica-se alguma semelhança com resultados do Sightsmap, embora entre as fotos coletadas haja maior destaque para as praias da região da rodovia Interpraias, mais agrestes e com menor ocupação - Laranjeiras e Estaleirinho -, seguidas por lugares ao longo da praia, com maior urbanização e verticalidade - Praia Central, Barra Sul e Pontal Norte. Finalizam o ranking, respectivamente, o parque Unipraias, o teleférico na Barra Sul, Interpraias, morro do Careca, praia dos Amores e o Cristo Luz. É importante destacar que os fatores climáticos e o período do ano - junho e julho (outono e inverno) - podem ter interferido nos resultados, já que determinadas condições podem estimular a prática de algumas atividades e a utilização e apropriação de algumas áreas em detrimento de outras. 
Ainda quantitativamente, foram levantados os elementos constantes nas fotos (figuras 3 e 4). Os elementos naturais componentes da paisagem foram representativamente superiores, podendo indicar sua relevância nessas paisagens, assim como a imagem de Balneário Camboriú enquanto destinação turística. Mesmo assim, a presença de elementos culturalmente construídos e integrantes da paisagem, especialmente na região central da cidade, como o skyline dos prédios, é identificada em boa parte das fotografias (figura 3). Conforme já destacado, a presença representativa das selfies confirma sua importância na construção da memória visual (MULLINS, 2014).

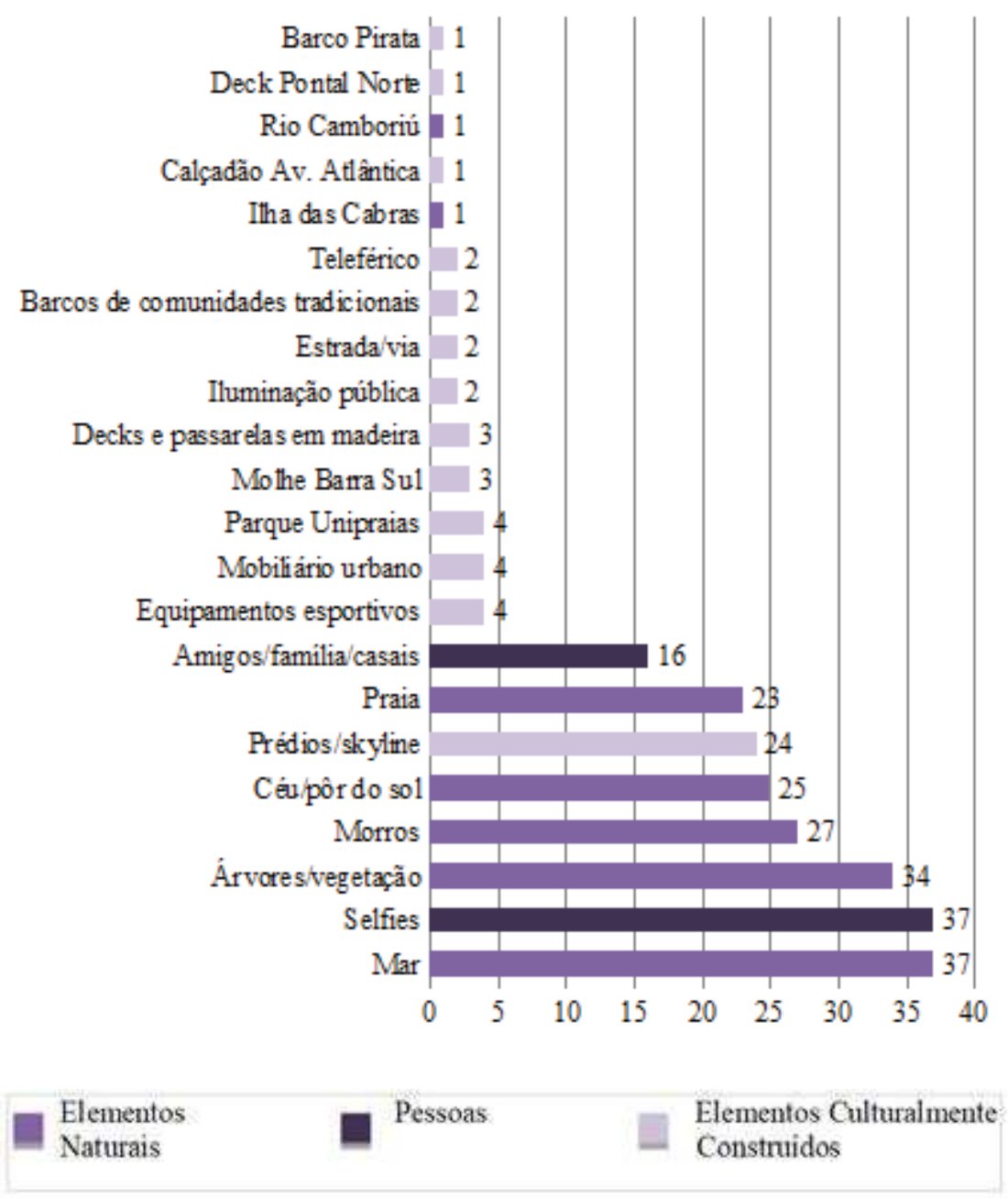

Figura 3 Ocorrência de elementos nas cenas das fotografias coletadas do Instagram, via Scup, em junho e julho de 2014.

Fonte: Luciana Noronha Pereira e Alina Gonçalves Santiago, 2014. 


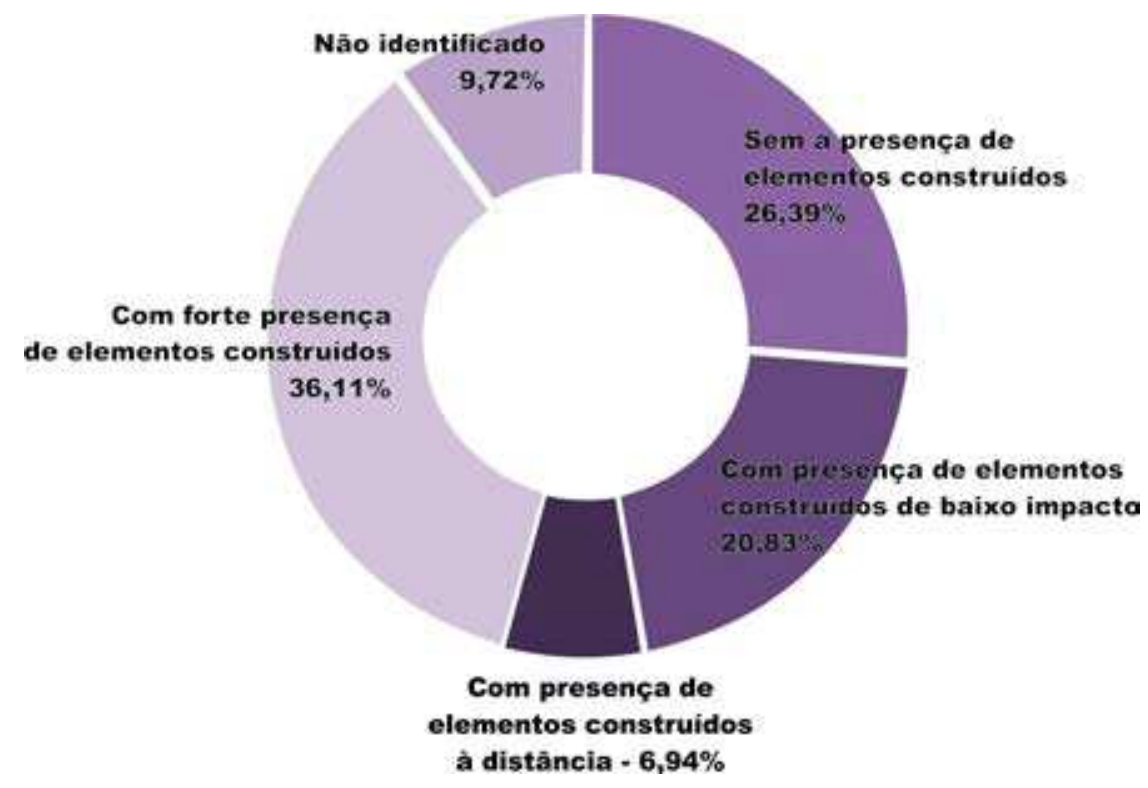

Figura 4 Presença de elementos construídos nas fotografias.

Fonte: Luciana Noronha Pereira e Alina Gonçalves Santiago, 2014.

Complementarmente, a partir de uma abordagem qualitativa, as 72 fotografias coletadas pelo Scup passaram por uma análise de abordagem semiótica de sua composição fotográfica, incluindo aspectos como enquadramento, elementos constituintes, cores e iluminação, emolduramento, assim como as atividades desenvolvidas, ideias e construções estéticas que podem estar relacionadas. Os comentários associados a essas fotografias, quando existentes, também passaram por análise de conteúdo. Para que essa tarefa seja possível, o sistema do Scup permite acessar um a um os itens coletados com as informações completas postadas por seus autores. Em razão de preservar os participantes da pesquisa, rostos e nomes dos autores e demais usuários que comentam as fotos foram omitidos.

Nos comentários, os conteúdos encontrados são positivos e transmitem, principalmente, ideias de felicidade, satisfação e relaxamento, de qualidade de vida através da prática de atividades físicas na praia, saudades de momentos bons, referência às férias ou aos dias de descanso na semana, beleza da paisagem ou de elementos naturais - diversas vezes associada a condições climáticas ou momentos do dia (nascer/pôr do sol). Nessas imagens está presente um recorte da paisagem em que há predominância de elementos naturais (ainda que ocorra a presença de elementos oriundos da intervenção humana), incluindo, de maneira recorrente, cores, aspectos de iluminação e atmosfera do nascer do sol (figura 5). 

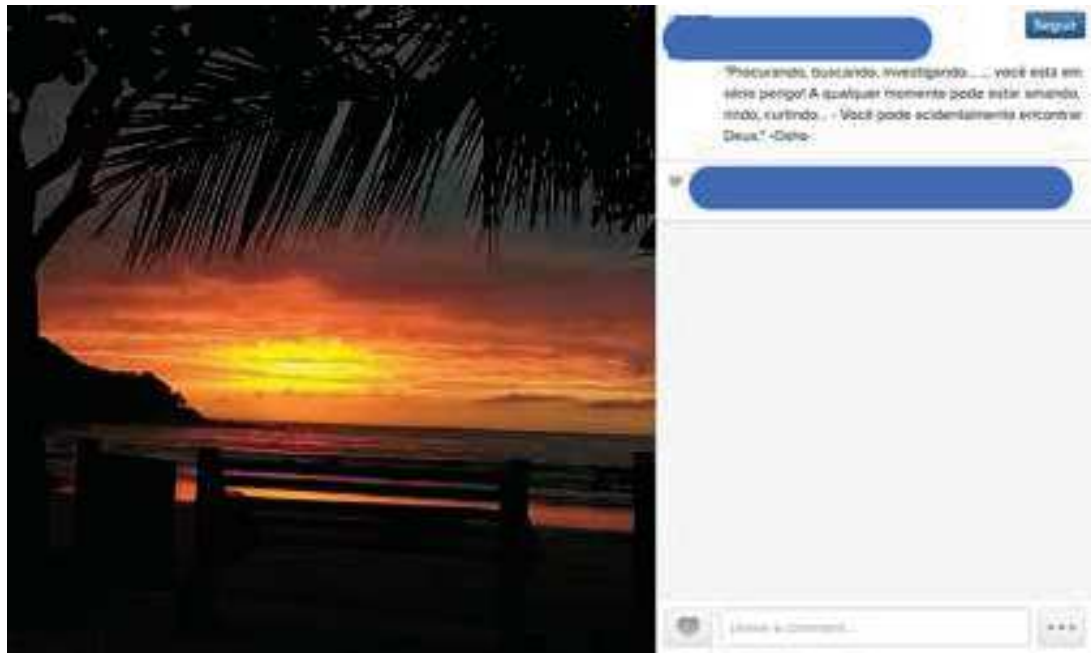

Figura 5 Ideia de presença divina associada ao nascer do sol e a elementos naturais, mesmo com a presença de intervenção humana - noção de convivência em harmonia. Fonte: Scup, 2014

Mesmo a ocorrência de palavras negativas, como "medo", quando tomada no contexto do comentário, possui conotação positiva. Neste caso, tais palavras sempre apareceram associadas às ideias de aventura, vencer o medo, aproveitar o dia, ou às atividades disponíveis (no parque Unipraias, o teleférico e a tirolesa em meio à mata atlântica) - e sempre enfatizando elementos naturais, ainda que em contato com a presença/intervenção humana - em todos os resultados coletados ao longo deste levantamento (figura 6).
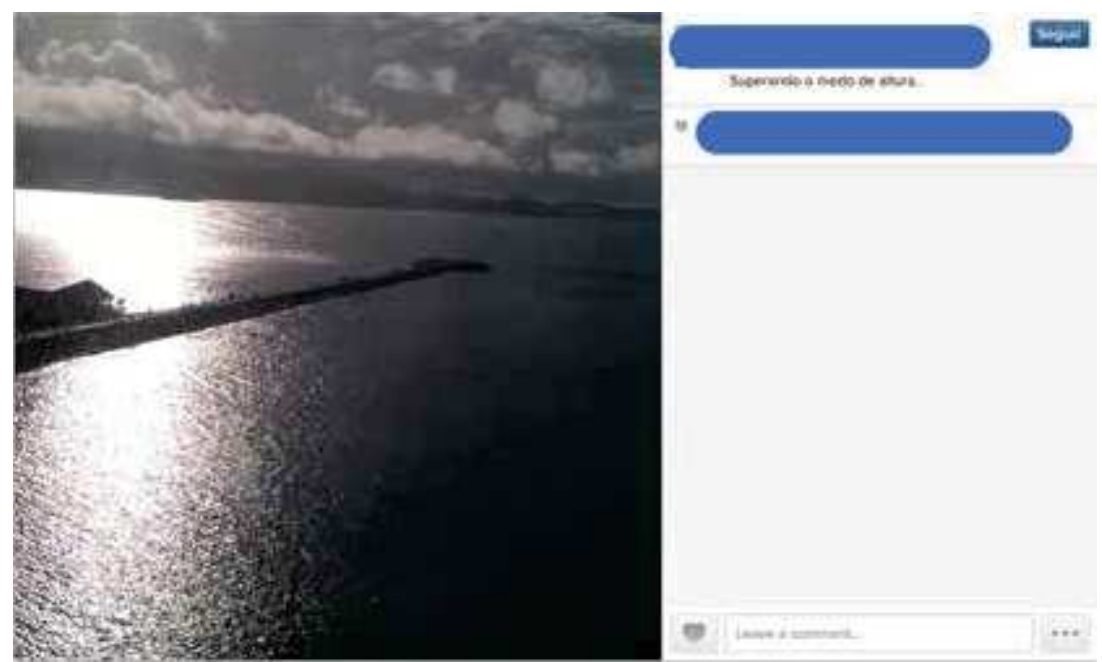

Figura 6 O termo "medo" - e sua superação para a utilização do teleférico - registrando predominantemente elementos naturais, mesmo com intervenção humana. Fonte: Scup, 2014. 
A prática de atividades físicas em áreas de orla também está presente com alguma recorrência nesses resultados. A ideia de qualidade de vida, força e energia, compartilhamento com amigos e lazer, com frequência está associada aos comentários desses registros. A possibilidade de realizar atividades à beira-mar, na praia e com a cidade como cenário, é enfatizada nas fotos. A maioria dos registros destacam o locus da prática e o cenário - cidade ou conjunto mar e morros em um plano mais afastado (figura 7).

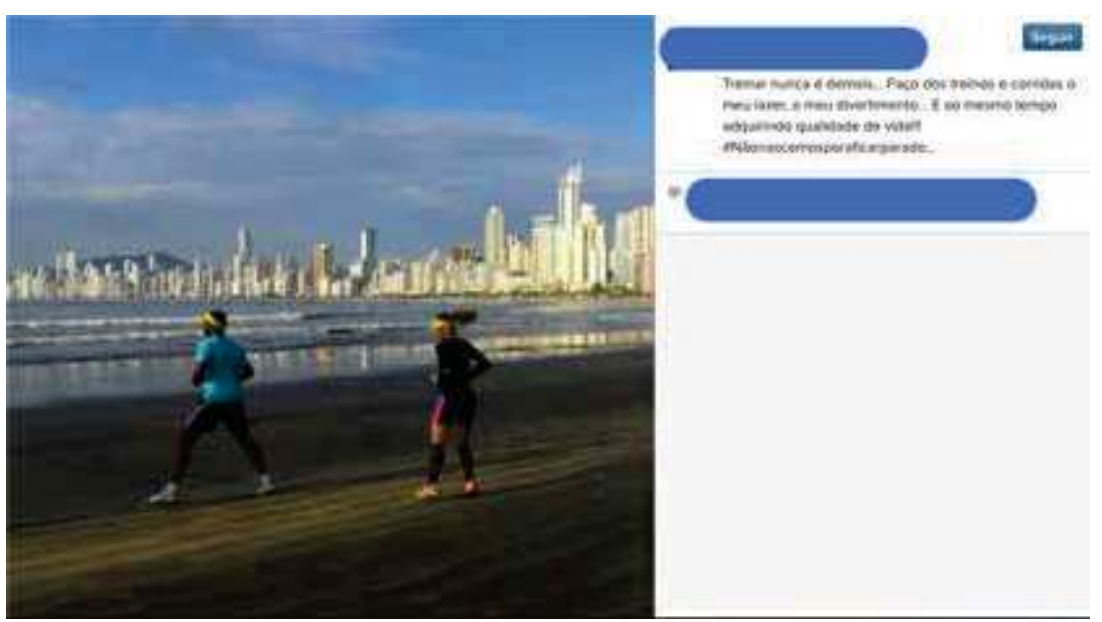

Figura 7 Atividades físicas na praia, como lazer e qualidade de vida, tendo a cidade como plano de fundo. Fonte: Scup, 2014.

Sentimentos de felicidade e paz são especialmente associados aos comentários de imagens em que há pouca movimentação e até mesmo certo bucolismo. Nesses casos, os registros centram-se na contemplação da paisagem, especialmente nos elementos naturais, e da cultura tradicional relacionada àquele contexto, apesar de algumas contarem com a presença da cidade, sua concentração e verticalização em plano de fundo.

O argumento da foto parece tratar "felicidade" como a presença dos elementos naturais e da cultura tradicional e algum distanciamento da movimentação urbana, como se a agitação, o barulho e a intensa ocupação estivessem ausentes. A ausência de pessoas também é um traço a ser ressaltado nas imagens, ainda que apareçam indiretamente, através de suas intervenções no espaço e equipamentos. No caso da figura 8, a ausência de pessoas se repete na escolha dos argumentos e o enquadramento valoriza a presença dos elementos naturais, omitindo boa parte da intervenção humana no local e dando as costas à cidade, que, a oeste desse mesmo ponto, tem intensa densidade construída e verticalização. $\bigcirc$ comentário dessas fotografias vem associado, ainda, à ideia de "paraíso". 


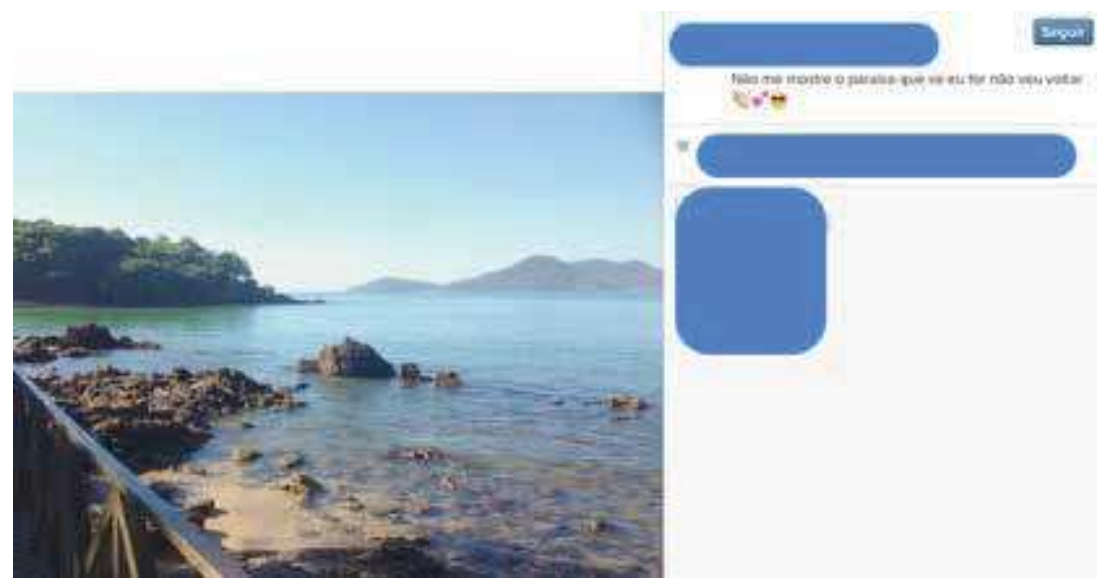

Figura 8 Associação da ideia de paraíso aos elementos naturais da paisagem. Fonte: Scup, 2014.

Outras fotos, sem comentários, mas também com o argumento central na contemplação da paisagem - especialmente com ênfase e predominância de elementos naturais ou de elementos da cultura popular local e ausência de pessoas - também puderam ser fortemente identificadas entre os resultados (figuras 9 a 12). Nestas fotografias, a poética associada à composição e enquadramento, escolha dos recortes e aproveitamento da luz (figuras 11 e 12), parece pretender valorizar os contornos ou a silhueta dos elementos naturais, conferindo-lhes caráter de paraíso e até de certa singeleza.
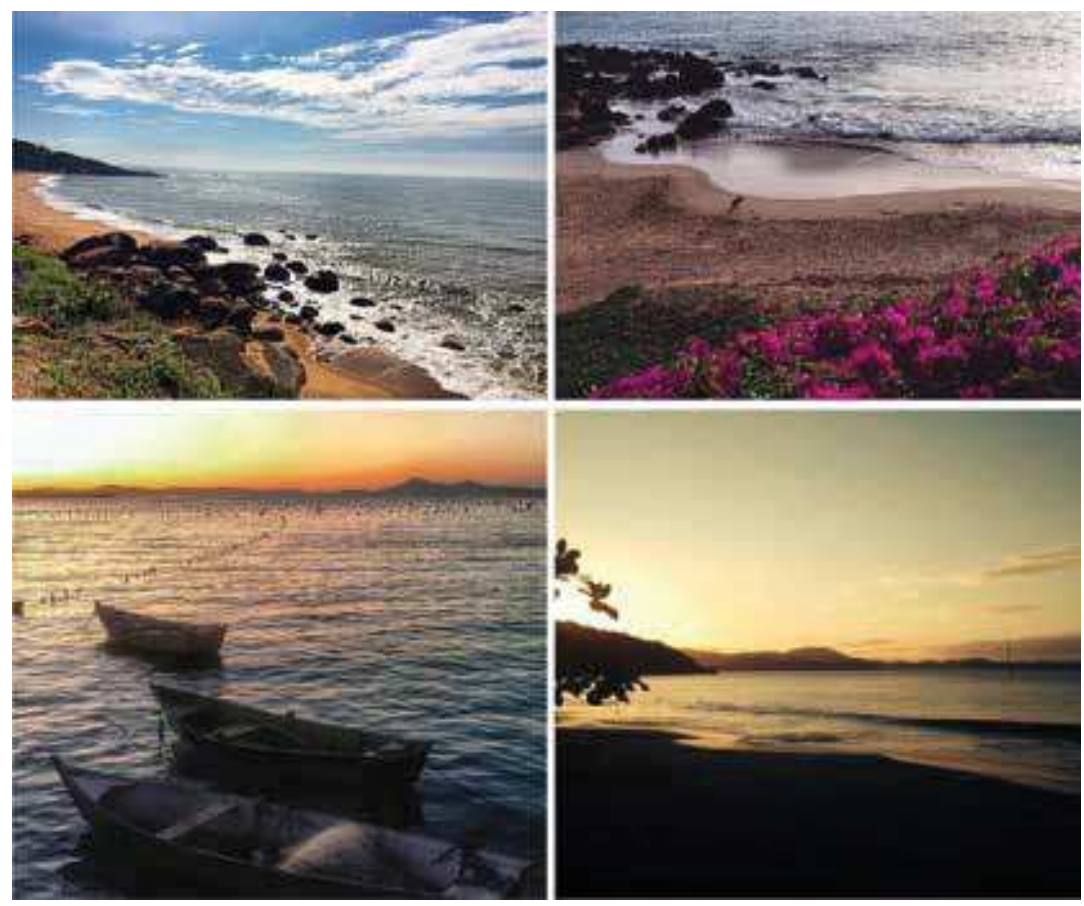

Figuras 9, 10, 11 e 12 Registros fotográficos com predominância dos elementos naturais. Fonte: Scup, 2014 
Já as quatro fotografias apresentadas em sequência (figuras 13 a 16), apesar de também excluírem a presença humana direta e de manterem atitude poética nos argumentos e nas escolhas de composição, enquadramento, recortes, luz, entre outros, contextualizam a presença urbana, através da massa edificada e demais elementos, como integrante da paisagem.

Ainda assim, em algumas das fotos, as edificações mantêm-se em plano de fundo, delineando o skyline da cidade, seja em sua silhueta ou presença, no conjunto de morros, mar, vias/calçadão, praças, mobiliário urbano, prédios. Poucas têm elementos socialmente construídos como argumento principal - como é o caso da figura 14, na qual a estrutura do teleférico, a vista para a crescente verticalização da Barra Sul e seu molhe ocupam posição de destaque, ainda que acompanhada dos elementos naturais.
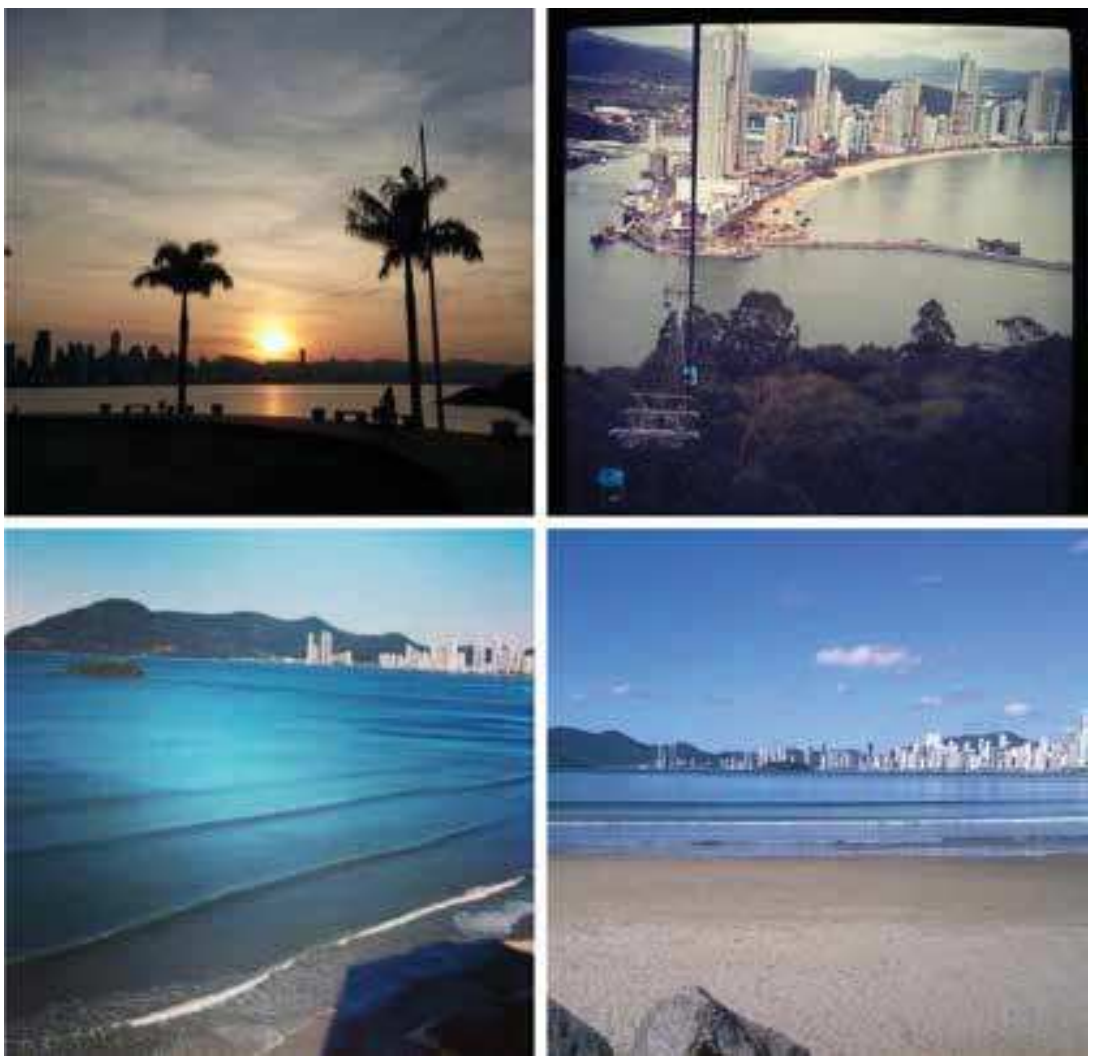

Figuras 13, 14, 15 e 16 Registros fotográficos com presença significativa de elementos urbanos.

Fonte: Scup, 2014.

Ao contrário dos registros fotográficos anteriores, nos quais a presença de pessoas não pode ser identificada, o fenômeno atual das selfies, nesta análise agrupado aos retratos, tem as pessoas em primeiro plano nas fotos, ocupando destaque entre os itens levantados pelo Scup (figuras 17 a 22). 

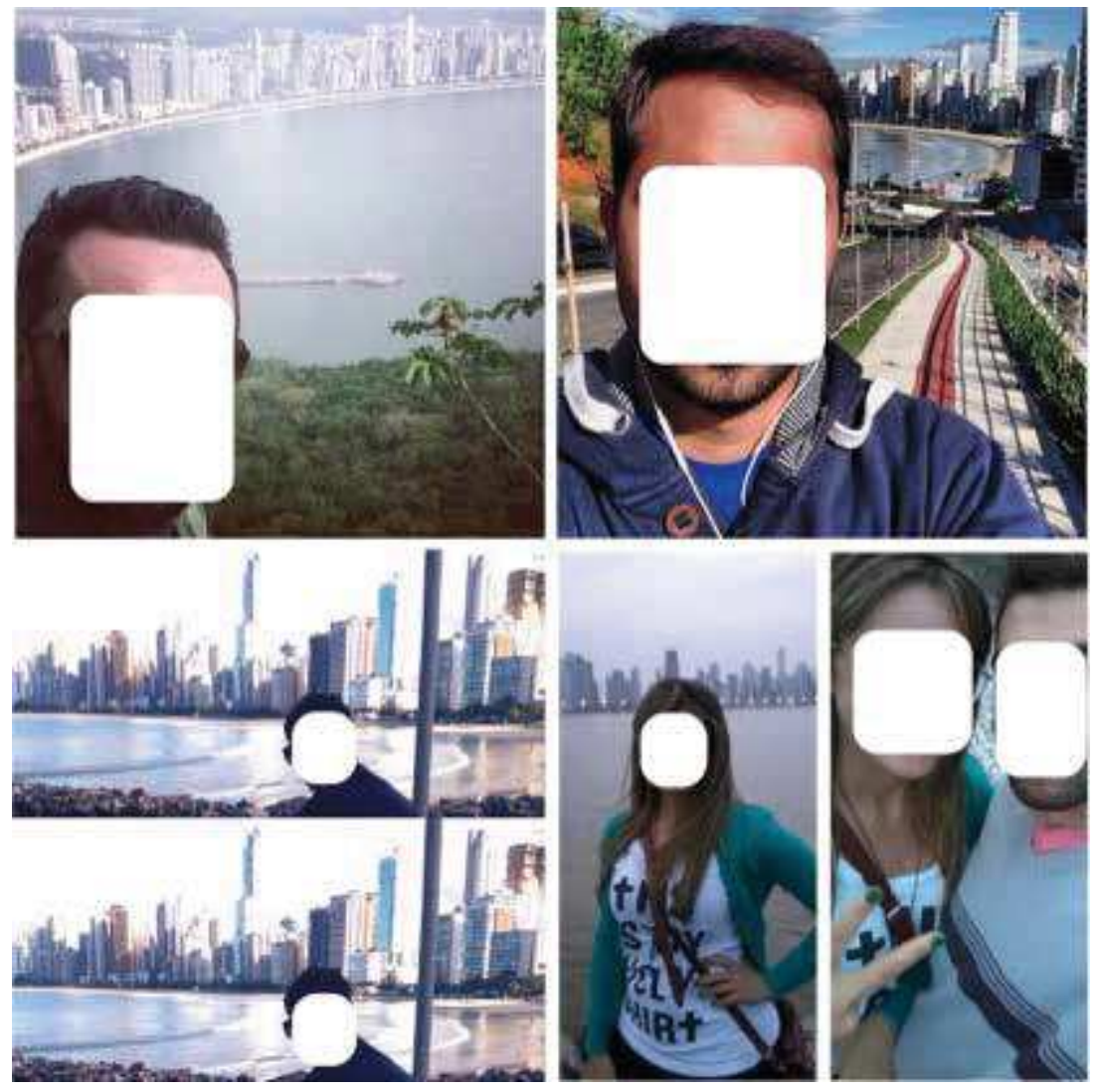

Figuras 17, 18, 19 e 20 Selfies e retratos associados diretamente à ocupação urbana, com significativa presença da orla, praia e mar. Fonte: Scup, 2014.
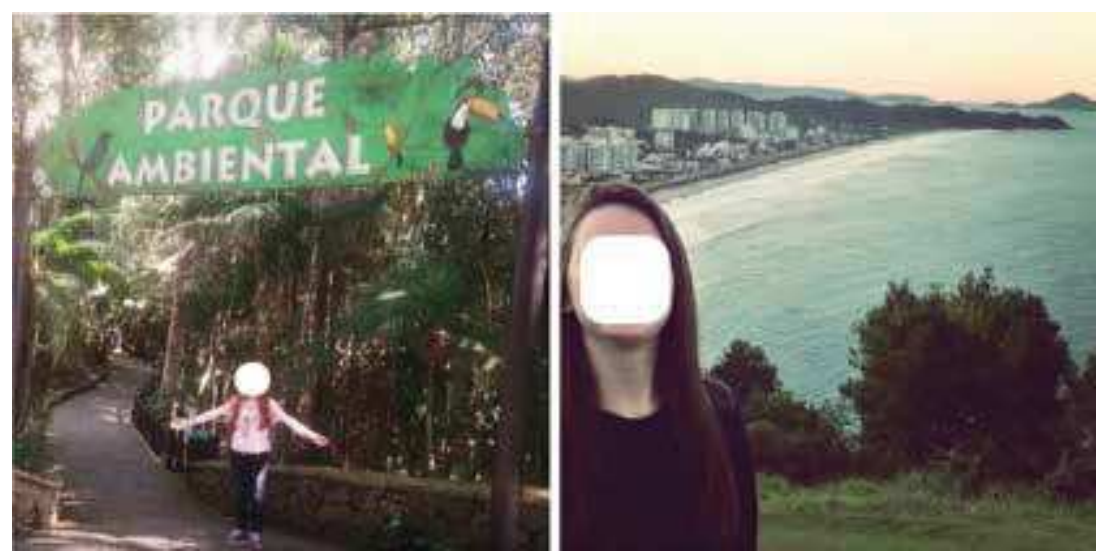

Figuras 21 e 22 Selfies e retratos associados predominantemente a elementos naturais, com presença de elementos urbanos. Fonte: Scup, 2014.

A maioria destes registros parece pretender a captura daquelas mesmas paisagens, alvo das fotografias comentadas anteriormente, mas procurando integrar a presença do usuário do espaço, turista ou visitante, naquela paisagem. Tal como preconiza Mullins (2014), mais do que comprovar a presença na destinação turística, tais selfies parecem 
buscar a inserção do sujeito naquele contexto espaço-temporal (SANTOS, 1992), auxiliando na construção da experiência de viagem (LO; MCKERCHER; CHEUNG, 2011) através de uma narrativa imagética (LARSEN, 2005).

Do mesmo modo, também no grupo de fotografias tipo selfies e retrato, os itens foram coletados pela inclusão de uma referência espacial pelo usuário, tendo sido identificadas fotografias nas quais os atributos da paisagem pouco integram a composição fotográfica. Nesses casos, o argumento principal das fotos são as pessoas e seus laços afetivos, marcado notadamente pela presença de grupos de amigos, casais, entre outros (figuras 23 e 24). Cumpre registrar que tais processos afetivos também têm papel fundamental nas vivências e, portanto, na definição das memórias, nas relações sujeito-espaço, na construção de significados.
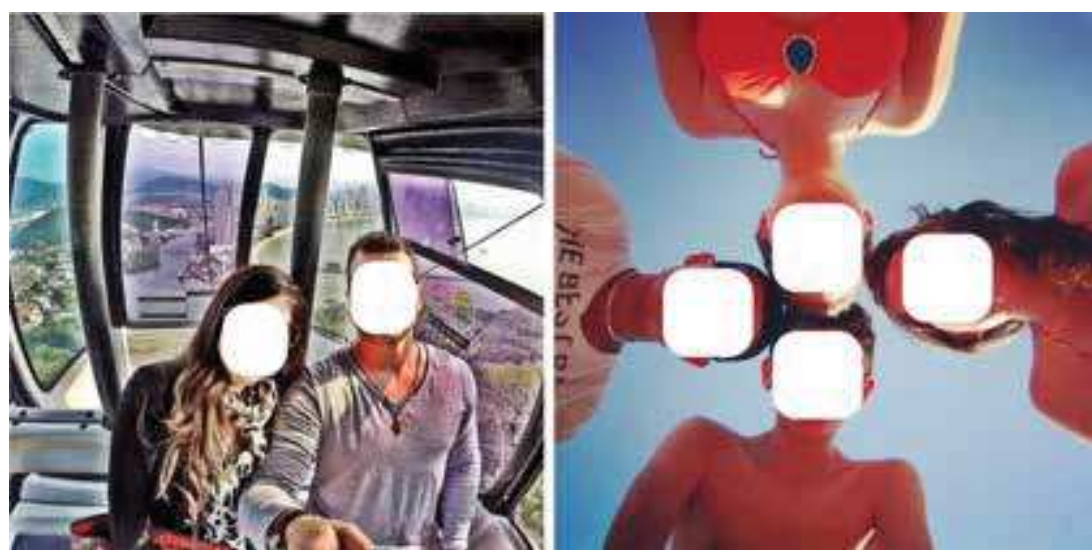

Figuras 23 e 24 Fotografias cujos temas são as pessoas e seus laços afetivos. Fonte: Scup, 2014.

Se, por um lado, a presença de selfies, bem como fotografias de casais, com familiares e amigos, é recorrente, demonstrando a importância dos vínculos afetivos e emocionais na experiência turística e na apropriação e significação da paisagem a partir de seus elementos, por outro lado, pode ser observada uma expressiva quantidade de registros fotográficos em que a ausência de pessoas no primeiro plano (em torno de 33\%) também pode indicar uma ânsia de distanciamento em relação à ocupação e à presença humana, e a procura de certo bucolismo, mesmo em paisagens fortemente marcadas pela ocupação urbana intensiva e verticalizada.

A concentração dos registros fotográficos nas áreas de orla, e/ou de interesse turístico, denuncia o desinteresse, ou mesmo a exclusão do restante da cidade, seja por falta de atrativos ou interesse, seja por falta de permeabilidade de outras áreas aos turistas e visitantes. Neste caso, seria oportuno buscar identificar as razões em um próximo estudo.

Independente dos questionamentos surgidos a partir destes resultados, que podem originar novos estudos, a ausência ou pouca expressividade das fotografias de outras áreas da cidade acaba por definir e delimitar a imagem da cidade de Balneário Camboriú como "a Balneário Camboriú da avenida Atlântica" ou "a Balneário Camboriú 
das praias", praticamente excluindo de sua imagem elementos e paisagens de outros bairros ou mesmo do interior dos bairros nos quais as fotos foram realizadas.

\subsection{CATEGORIAS PRELIMINARES DE FRAGMENTOS DA PAISAGEM ONLINE}

A realização de um agrupamento preliminar dos resultados deu origem à aproximação categórica inicial aqui proposta, extraída dos dados coletados online. Cinco categorias preliminares são apresentadas a seguir:

a. fragmento da paisagem como paraíso: inclui imagens fotográficas e conteúdos verbais que apontam para a ideia do belo, especialmente enfatizando os elementos naturais, da cultura popular, ou, ainda, uma iluminação diferenciada. A ideia de exaltação aos elementos naturais e seus atributos "divinos", satisfação, felicidade e prazer, constava nos comentários associados às fotografias - casos em que raramente as pessoas participavam da cena;

b. fragmento da paisagem como cenário: inclui imagens fotográficas e comentários apontando para a paisagem como cenário humano. Ainda que também trouxesse as noções de prazer e satisfação, estas não eram atribuídas diretamente aos elementos da paisagem, mas às atividades desenvolvidas pelas pessoas com a presença da paisagem;

c. fragmento da paisagem como locus da existência humana: o primeiro plano das imagens desta categoria são as pessoas, sua inserção no local e os laços afetivos que as conectam. Inclui retratos e selfies que possuem a existência humana e suas relações como argumentos centrais. Em alguns casos, a paisagem é o cenário no qual o sujeito busca se inserir, comprovando sua presença e existência; em outros, a paisagem é praticamente ausente ou surge na sobra do enquadramento;

d. fragmento da paisagem do consumo: inclui imagens e informações verbais relativas às experiências de consumo. Uso do comércio abundante e diversificado, assim como a ideia de exclusividade, luxo e compras associada a determinados locais e/ou ângulo de visão privilegiado;

e. paisagem oculta: inclui fotografias e comentários que não estabelecem relação visual ou verbal com a paisagem. Tendo em vista o interesse central deste estudo, esta categoria, embora identificada, foi abandonada como opção da pesquisa, podendo ser retomada em outra investigação. 


\section{OUTRAS CONSIDERAÇÕES}

Entendendo a paisagem enquanto produto/produtora de determinada sociedade e seu contexto no que diz respeito ao seu papel na atratividade turística - sendo o turismo um fenômeno da sociedade contemporânea -, torna-se fundamental compreender as leituras, sensações e significados que podem ser relacionados a ela e a seus elementos.

Do mesmo modo, ciente de que o espaço - tanto quanto outras tecnologias produzidas em cada momento da humanidade - só é possível através de sua construção social, pode-se dizer que são as mudanças no meio técnico-científico-informacional que determinam ajustes e alterações nas atividades humanas, que também se refletem no espaço e no processo de apropriação e significação (SANTOS, 1996).

Nesse sentido, as novas TICs têm alterado as relações sociais, as formas de produção e apropriação do espaço, as lógicas de produção e divulgação de informações, entre as quais a fotografia. Esta, compreendida como categoria imagética complexa, capaz de transmitir ideias, conceitos e significados, pode ser enquadrada como linguagem, permitindo a construção da imagem de determinado lugar mesmo antes do contato com ele. No caso da experiência turística, os registros fotográficos permitem torná-la, de certo modo, tangível, auxiliando na formação das memórias, na inserção do sujeito no contexto em questão, na construção de uma narrativa que estruture tal experiência.

Os resultados encontrados para a localidade de Balneário Camboriú incluem classes de imagens que se diferenciam essencialmente na presença ou ausência de pessoas em primeiro plano, na negação do urbano para uma poética ligada aos elementos naturais ou na presença urbana em plano de fundo, como cenário junto ao mar. Os comentários, quando presentes, foram positivos. A vida perto do mar foi relacionada à ideia de qualidade de vida, pelo contato com a natureza, condições do clima, momentos do dia, pela prática de atividades físicas ou pela sensação de felicidade associada ao mar ou outros elementos naturais.

As fotografias coletadas concentram-se em áreas de interesse turístico, podendo indicar desinteresse, falta de atrativos ou até mesmo negação de outras áreas da cidade. É importante frisar que as áreas de orla são também as mais valorizadas pelo interesse imobiliário, com concentração da população de maior renda e infraestrutura, com mais investimentos do poder público municipal.

A ampliação da utilização e do acesso às novas TICs, associada a uma maior oferta de informações, tem permitido que mosaicos de milhares de fotografias cheguem até as pessoas e atuem como mediadores na construção da imagem da cidade e seus significados, para muito além da própria atividade turística. Nesse sentido, é possível que se esteja em um período de transição que interferirá de modo definitivo no processo por meio do qual é realizada a apreensão da cidade, em busca de elementos que possibilitem sua legibilidade e a criação de sua imagem mental. 


\section{REFERÊNCIAS BIBLIOGRÁFICAS}

BENI, M. C. Política e estratégia do desenvolvimento regional: planejamento integrado e sustentável do turismo. Revista Turismo em Análise. São Paulo, v. 10, maio, 1999, p. 7-17.

BUTLER, R. W. The concept of a tourist area life cycle of evolution implications for management of resources. Canadian Geographer, v. 24, n. 1, 1980, p. 5-12.

CAPRA, F. As conexões ocultas: ciência para uma vida sustentável. São Paulo: Cultrix, 2002.

CASARIN, V.; SANTIAGO, A. G. Uma reflexão acerca do papel do arquiteto na construção da paisagem informacional. Paisagem e Ambiente: ensaios, n. 31. São Paulo: FAUUSP, 2013, p. 147-160.

CONCU, N.; ATZENI, G. Conflicting preferences among tourists and residents. Tourism Management, 33, 2012, p. 1.293-1.300.

CORREA, R. L. O espaço urbano. 3 ed. São Paulo: Ática, 1995. (Série Princípios).

; ROSENDAHL, Z (Orgs.). Paisagem, tempo e cultura. Rio de Janeiro: UERJ, 1998.

COSTA, M. M.; BENITES, M. G. Realismo na fotografia: um ensaio sobre o estudo da linguagem fotográfica para o ensino de geografia. Geoatos - Geografia em Atos, Presidente Prudente: UNESP, v. 2, n. 9, 2009. Disponível em: $<$ revista.fct.unesp.br/index.php/geografiaematos/article/download/283/costan9v2>. Acesso em: jun. 2015.

DUARTE, F.; FIRMINO, R. Infiltrated city, augmented space: information and communication technologies, and representations of contemporary spatialities. The Journal of Architecture. Volume 14 (5), 2009.

DOI: http://dx.doi.org/10.1080/13602360903187493

DUBOIS, P. O ato fotográfico e outros ensaios. 7 ed. Campinas: Papirus, 2003.

GOELDNER, C. R.; MCINTOSH, R. W.; RITCHIE, J. R. Turismo: princípios, práticas e filosofias. São Paulo: Bookman, 2002.

KOSSOY, B. Realidades e ficções na trama fotográfica. 3 ed. Cotia: Ateliê Editorial, 2002.

KRAMER, A.; GUILLORY J.; HANCOCK, J. Experimental evidence of massive-scale emotional contagion through social networks. National Academy of Sciences of the United States of America. Proceedings. Washington, DC: National Academy of Sciences, v. 11 1, n. 24, June 2014, p. 8.788-8.790. Disponível em: < http://www.pnas.org/ content/1 1 1/24/8788.full >. Acesso em: jun. 2014. DOI: 10.1073/pnas.1320040111

LAMAS, J. M. R. G. Morfologia urbana e desenho da cidade. 2 ed. Lisboa: Fundação Calouste Gulbekian, 2004. Cap. I e II. p. 17-129.

LARSEN, J. Families seen sightseeing: performativity of tourist photography. Space and Culture. Vol. 8, No. 4, November, 2005, p. 416-434. Disponível em: <http://sac.sagepub.com/content/8/4/416>. Acesso em: jul. 2014. DOI: $10.1177 / 1206331205279354$

LEITE, M. A. F. P. Destruição ou desconstrução? Questões de paisagem e tendências de regionalização 2 ed. São Paulo: Hucitec, 2006.

LEMOS, A. Celulares, funções pós-midiáticas, cidade e mobilidade. URBE - Revista Brasileira de Gestão Urbana. Curitiba: PUC, v. 2, n. 2, jul./dez., 2010, p. 155-166.

LIZ, A. A.; PEREIRA, L. N. Implicações das políiticas públicas na morfologia urbana em Balneário Camboriú/SC. In: SEMINÁRIO DE INICIAÇÃO CIENTÍFICA, 12, Itajaí: UNIVALI, 2013.

LO, I.; MCKERCHER, Lo A.; CHEUNG, L. Tourism and online photography. Tourism Management, 32, 2011 , p.

725-731. Disponível em: <http://www.sciencedirect.com/science/journal/02615177>. Acesso em: jul. 2014.

DOI: 10.1016/j.tourman.2010.06.001

MALARD, M. L. As aparências em arquitetura. Belo Horizonte: UFMG, 2006.

MARCHI, P. M. de. Cell phones: a digital cartography of São Paulo. URBE - Revista Brasileira de Gestão Urbana. Curitiba: PUC-PR, v. 6, n. 1, jan./abr., 2014, p. 73-85. Disponível em: < http://www2.pucpr.br/reol/pb/index.php/ urbe? $\mathrm{dd} 1=12403 \& d d 99=$ view\&dd98=pb $>$. Acesso em: out. 2015.

MULLINS, P. Archaeology and material culture: the material world, broadly defined. Imagining heritage: selfies and visual placemaking at historic sites, 2014. Disponível em: <http://paulmullins.wordpress.com/2014/06/30>. Acesso em: jul. 2014.

OLIVEIRA, J. P.; FERNANDES, D. L.; STACH, C. A paisagem urbana como recurso turístico: um estudo da paisagem edificada de Irati - PR enquanto atrativo turístico. Turismo - Visão e Ação. vol. 9, n. 1, jan./abr., 2007, p. 83-94. 
Redes Sociais e Paisagem da Destinação Turística: Fotografias Online na Construção da Imagem da Cidade

REED, D. J.; JOHNSON, M. R. New technological localisms: a comparative analysis of two case studies. URBE - Revista Brasileira de Gestão Urbana, Curitiba: PUC, v. 6, n. 1, jan./abr., 2014, p. 57-72. Disponível em: $<$ http://dx.doi.org/10.7213/urbe.06.001.SE4>. Acesso em: ago. 2016.

RUSCHMANN, D. M. Turismo e planejamento sustentável: a proteção do meio ambiente. 10 ed. Campinas: Papirus, 2003

SANTAELLA, L.; NÖTH, W. Imagem: cognição, semiótica, mídia. São Paulo: Luminuras, 1998.

SANTOS, M. Espaço e método. 3 ed. São Paulo: Nobel, 1992.

Técnica, espaço, tempo: globalização e meio técnico-científico-informacional. São Paulo: Hucitec, 1994.

A natureza do espaço: técnica e tempo, razão e emoção. São Paulo: Hucitec, 1996.

TACCA, F. Imagem fotográfica: aparelho, representação e significação. Psicologia \& Sociedade. Porto Alegre: UFRGS, v. 17, n. 3, set./dez, 2005. DOI: http://dx.doi.org/10.1590/S0102-71822005000300002.

URRY, J. O olhar do turista. São Paulo: Studio Nobel, 1999.

VERDUM, R. Perceber e conceber paisagem. In: VERDUM, R.; VIEIRA, L. dos S.; PINTO, B. F.; SILVA, L. A. P (Orgs.) Paisagem: leituras, significados e transformação. Porto Alegre: UFRGS, 2012.

XIANG, Zheng; GRETZEL, Ulrike. Role of social media in online travel information search. Tourism Management, 31, 2010, p. 179-188. DOI: <http://dx.doi.org/10.1016/i.tourman.2009.02.016>. 